\title{
Pelvic organ prolapse quantification system: to valsalva or not to valsalva while measuring genital hiatus (GH) and perineal body (PB)
}

\section{Tapaswini Hota, Sujata Misra*}

Department of Obstetrics and Gynecology, SCB Medical College, Cuttack, Odisha, India

\begin{abstract}
Received: 27 March 2017
Accepted: 03 April 2017
\end{abstract}

\author{
*Correspondence: \\ Dr. Sujata Misra, \\ E-mail: drsujatamisra@gmail.com
}

Copyright: (c) the author(s), publisher and licensee Medip Academy. This is an open-access article distributed under the terms of the Creative Commons Attribution Non-Commercial License, which permits unrestricted non-commercial use, distribution, and reproduction in any medium, provided the original work is properly cited.

\begin{abstract}
Background: It is a study to determine whether or not, the widening of GH and PB with valsalva is evidence of pelvic floor dysfunction, and by the logic should the values in POPQ staging, be taken at valsalva or at rest.

Methods: Prospective 2 arm cohort study. However, the analysis of various risk factors for prolapse was done in a case control study manner.

Results: As compared to women without prolapse, in patients with POP, the dimensions of GH and PB are higher. Also, the increase in their dimensions with valsalva is more in prolapse cases. So valsalving while measurement of $\mathrm{GH}$ and $\mathrm{PB}$ would give a better idea of pelvic floor dysfunction.

Conclusions: The study shows association between the severity of urinary problems and degree of prolapse. Measurements of POPQ when taken during valsalva, tend to give a better picture of levator dysfunction in prolapse patients.
\end{abstract}

Keywords: Calibrated swab stick, Genital hiatus, Pelvic organ prolapse quantification, Perineal body, Quality of life

\section{INTRODUCTION}

It is significant that Pelvic organ prolapse and its associated disorders, although were never life threatening, continued to have a major impact on QOL. Even though there were different systems proposed for its staging, none has proved itself to respond to all the requirements of the medical community, so the vast majority were short lived, failing to become the single most useful system for POP staging. POPQ is currently the most quantitative and site specific system of staging and has received the recognition of TNM system in oncology. ${ }^{1}$ The original description of POPQ doesn't specify as to whether GH and PB measurements should be done in resting or during straining position. Hence methodology adopted by various practioners vary. ${ }^{2} \mathrm{Visco}$ et al observed significant increase in $\mathrm{GH}$ and $\mathrm{PB}$ during valsalva, but it's not clear this is a normal phenomenon or an evidence of pelvic floor dysfunction. ${ }^{2}$

Reviewing the literature, the major risk factors associated with prolapse are unassisted vaginal delivery and increasing parity. ${ }^{3,4}$ Decrease in sexual hormones after menopause, straining (constipation, chronic cough, occupational physical stress or obesity) associated with increased intra-abdominal pressure is also shown by various studies to be strong risk factors. ${ }^{5-15}$

As shown by a study, hiatal ballooning can be predicted by $\mathrm{GH}$ and $\mathrm{PB}$ measurements, with their sum $(\mathrm{GH}+\mathrm{PB}>7)$ being a stronger predictor than individual measurements. ${ }^{16}$

This study aims to support the idea of measuring hiatal diameters while valsalva. It further aims to determine 
strength of association of POP with various epidemiologic risk factors and aggravation of symptoms of urinary urge and incontinence with degree of prolapse

\section{METHODS}

The study was carried out in the department of Obstetrics and Gynecology, SCB Medical College and Hospital, Cuttack for a period of 24 months (October 2012 to October 2014). Methods and conditions for POPQ staging, as standardized by ICS and American Urogynaecologic society and was followed in the study. The study received clearance from the institutional ethics committee. History regarding various life events as a possible risk factor for prolapse was recorded.

Current symptoms of urgency and incontinence was also asked. POPQ staging was done. All measurements were taken in the patients at rest in dorsal lithotomy position, with the help of POPSTICK. SUI demonstrated. The measurements of POPQ were taken in 50 patients with $\geq$ stage 2 prolapse and in 50 other controls without prolapse. The same was repeated while straining. Increase in $\mathrm{GH}, \mathrm{PB}$ and their sum was compared in both the groups

\section{RESULTS}

Table 1 presents the age distribution of subjects along with the Chi square test of association. The Chi square test revealed that the age distribution among cases and controls is more or less the same.

In Table 2 when the subjects were further divided into 2 groups 18-39 yrs and $\geq 40 y r s$, and studied for the association with prolapse, it was found that there is a strong association of prolapse with the older age group ( $\mathrm{P}$ value $=0.000$ )

Table 1: Age distribution of subjects by case and control.

\begin{tabular}{|c|c|c|c|c|c|c|c|}
\hline \multirow{2}{*}{ Age group } & \multicolumn{2}{|c|}{ Case } & \multicolumn{2}{|c|}{ Control } & \multicolumn{2}{|c|}{ Total } & \multirow{2}{*}{$\chi^{2}, ' \mathbf{p}^{\prime}$} \\
\hline & No. & $\%$ & No. & $\%$ & No. & $\%$ & \\
\hline $18-29$ & 4 & 8.0 & 10 & 20 & 14 & 14 & \multirow{4}{*}{$\begin{array}{l}4.429 \\
p=0.109\end{array}$} \\
\hline $30-59$ & 24 & 48.0 & 26 & 52 & 50 & 50 & \\
\hline$\geq 60$ & 22 & 44.0 & 14 & 28 & 36 & 36 & \\
\hline Total & 50 & 100 & 50 & 100 & 100 & 100 & \\
\hline
\end{tabular}

Table 2: Age distribution of subjects by case and control.

\begin{tabular}{|c|c|c|c|c|c|c|c|}
\hline \multirow{2}{*}{ Age group } & \multicolumn{2}{|c|}{ Case } & \multicolumn{2}{|c|}{ Control } & \multicolumn{2}{|c|}{ Total } & \multirow{2}{*}{$\chi^{2}, p^{\prime}$} \\
\hline & No. & $\%$ & No. & $\%$ & No. & $\%$ & \\
\hline $18-29$ & 8 & 16 & 25 & 50 & 33 & 33 & \multirow{3}{*}{$\begin{array}{l}13.071 \\
p=0.000\end{array}$} \\
\hline $30-59$ & 42 & 84 & 25 & 50 & 67 & 67 & \\
\hline Total & 50 & 100 & 50 & 100 & 100 & 100 & \\
\hline
\end{tabular}

Odds ratio for group (Case/Control): Value 0.19 95\% CI Lower: 0.075, Upper: 0.486,

Risk Estimate: for cohort age group $=18-39$ value 0.32 , for cohort age group $=\geq 40$ value 1.68

Table 3: Parity distribution of subjects by case and control.

\begin{tabular}{|c|c|c|c|c|c|c|c|}
\hline \multirow{2}{*}{ Parity } & \multicolumn{2}{|c|}{ Case } & \multicolumn{2}{|c|}{ Control } & \multicolumn{2}{|c|}{ Total } & \multirow{2}{*}{$\chi^{2}, \mathbf{p}^{\prime}$} \\
\hline & No. & $\%$ & No. & $\%$ & No. & $\%$ & \\
\hline $0-2$ & 14 & 28 & 35 & 70 & 49 & 49 & \multirow{3}{*}{$\begin{array}{l}17.647 \\
0.000\end{array}$} \\
\hline $3-5$ & 36 & 72 & 15 & 30 & 51 & 51 & \\
\hline Total & 50 & 100 & 50 & 100 & 100 & 100 & \\
\hline
\end{tabular}

Odds ratio for group (Case/Control): Value 0.167, 95\% CI Lower: 0.70, Upper: 0.396,

Risk Estimate: For cohort parity group $=0-2$ Value 0.400 , For cohort parity group $=3-5$ Value 2.400

Table 4: Distribution of subjects by menopause by case and control.

\begin{tabular}{|c|c|c|c|c|c|c|c|}
\hline \multirow{2}{*}{ Menopause } & \multicolumn{2}{|c|}{ Case } & \multicolumn{2}{|c|}{ Control } & \multicolumn{2}{|c|}{ Total } & \multirow{2}{*}{$\chi^{2}, p^{\prime}$} \\
\hline & No. & $\%$ & No. & $\%$ & No. & $\%$ & \\
\hline Yes & 30 & 60 & 14 & 28 & 44 & 44 & \multirow{3}{*}{$\begin{array}{l}10.390 \\
p=0.001\end{array}$} \\
\hline No & 20 & 40 & 36 & 72 & 56 & 56 & \\
\hline Total & 50 & 100 & 50 & 100 & 100 & 100 & \\
\hline
\end{tabular}

Odds ratio for group (Case/Control): Value 3.857, 95\% CI Lower : 1.67, Upper $=8.911$,

Risk Estimate: For cohort Menopause $=$ Yes Value 2.143, For cohort Menopause $=$ No Value 0.556 
Table 5: Distribution of subjects by cough and constipation by case and control.

\begin{tabular}{|c|c|c|c|c|c|c|c|}
\hline \multirow{2}{*}{$\begin{array}{l}\text { Cough and } \\
\text { constipation }\end{array}$} & \multicolumn{2}{|c|}{ Case } & \multicolumn{2}{|c|}{ Control } & \multicolumn{2}{|c|}{ Total } & \multirow{2}{*}{$\chi^{2}, \mathbf{p}^{\prime}$} \\
\hline & No. & $\%$ & No. & $\%$ & No. & $\%$ & \\
\hline Yes & 26 & 52 & 15 & 28 & 41 & 41 & \multirow{3}{*}{$\begin{array}{l}5.022, \\
p=0.025\end{array}$} \\
\hline No & 24 & 58 & 35 & 72 & 59 & 59 & \\
\hline Total & 50 & 100 & 50 & 100 & 100 & 100 & \\
\hline
\end{tabular}

Odds ratio for group (Case/Control): Value 2.528, 95\% CI Lower : 1.112, Upper $=5.744$,

Risk Estimate: For cohort cough and Constipation = Yes Value 1.733, For cohort cough and Constipation= No Value 0.686

Table 6: Distribution of subjects by urinary symptoms by case and control.

\begin{tabular}{|c|c|c|c|c|c|c|c|}
\hline \multirow{2}{*}{$\begin{array}{l}\text { Urinary } \\
\text { symptoms }\end{array}$} & \multicolumn{2}{|c|}{ Case } & \multicolumn{2}{|c|}{ Control } & \multicolumn{2}{|c|}{ Total } & \multirow[b]{2}{*}{$\chi^{2}, p^{\prime}$} \\
\hline & No. & $\%$ & No. & $\%$ & No. & $\%$ & \\
\hline Present & 30 & 60 & 21 & 42 & 51 & 51 & \multirow{3}{*}{$\begin{array}{l}3.241 \\
\mathrm{p}=0.072\end{array}$} \\
\hline Absent & 20 & 40 & 29 & 58 & 49 & 49 & \\
\hline Total & 50 & 100 & 50 & 100 & 100 & 100 & \\
\hline
\end{tabular}

Odds ratio for group (Case/Control): Value 2.071, 95\% CI Lower : 0.933, Upper $=4.597$,

Risk Estimate: for cohort urinary symptoms= Present Value 1.429 , for cohort urinary symptoms= Absent 0.690

Table 3 shows a positive association of higher parity levels and therefore vaginal birth with prolapse $(\mathrm{P}$ value $0.0004)$.

Table 4 , study revealed $60 \%$ of the pateints with prolapse were post menopausal, while figure was only $28 \%$ for the controls, thus pointing out the statistically significant association of menopause with that of prolapse $(\mathrm{P}$ value $=$ $0.001)$.

Table 5 revealed that $52 \%$ of the prolapse pateints had a history of chronic cough or constipation, while only $28 \%$ of the controls reported it, thus a significant association ( $\mathrm{P}$ value of 0.025$)$.

In Table 6, both manifested and occult by SUI test showed significant association of prolapse with it $(\mathrm{P}=$ 0.000).

Table 7 comparing $\mathrm{GH}$ and $\mathrm{PB}$ at rest in cases and controls, the independant sample $t$ test computed $P$ value of 0.000 . Also, the mean increase of $\mathrm{GH}$ and $\mathrm{PB}$ with valsalva in cases, as compared to the resting state when compared to the corresponding increase in controls was found to be statistically significant $(\mathrm{P}=0.000)$.

Table 7: Comparison of GH and PB at rest and strain in cases and controls.

\begin{tabular}{|c|c|c|c|c|c|}
\hline & Group & $\mathbf{N}$ & Mean & Std. Deviation & Std. Error \\
\hline \multirow{2}{*}{ GH without valsalva } & Case & 50 & 3.56 & 0.41 & 0.06 \\
\hline & Control & 50 & 3.13 & 0.51 & 0.07 \\
\hline \multirow{2}{*}{$\begin{array}{l}\text { Increase in } \mathrm{GH} \text { with } \\
\text { valsalva }\end{array}$} & Case & 50 & 2.76 & 0.91 & 0.13 \\
\hline & Control & 50 & 1.16 & 0.91 & 0.13 \\
\hline \multirow{2}{*}{ PB without valsalva } & Case & 50 & 2.07 & 0.49 & 0.07 \\
\hline & Control & 50 & 1.74 & 0.35 & 0.05 \\
\hline \multirow{2}{*}{$\begin{array}{l}\text { Increase in PB with } \\
\text { valsalva }\end{array}$} & Case & 50 & 1.12 & 0.54 & 0.08 \\
\hline & Control & 50 & 0.52 & 0.40 & 0.06 \\
\hline \multirow{2}{*}{$\begin{array}{l}\mathrm{GH}+\mathrm{PB} \text { without } \\
\text { valsalva }\end{array}$} & Case & 50 & 4.63 & 0.62 & 0.09 \\
\hline & Control & 50 & 4.87 & 0.71 & 0.10 \\
\hline \multirow{2}{*}{$\begin{array}{l}\text { Increase in } \mathrm{GH}+\mathrm{PB} \text { with } \\
\text { valsalva }\end{array}$} & Case & 50 & 2.40 & 1.19 & 0.17 \\
\hline & Control & 50 & 1.68 & 0.74 & 0.10 \\
\hline
\end{tabular}

\section{DISCUSSION}

This study supports the fact that the incidence of uterovaginal prolapse increases with increasing age. Most studies examining prolapse or surgery for prolapse have reported the same. ${ }^{3,4}$ Labour aided by premature bearing down and undue physician's traction has a damaging effect on the intricately constructed support system of the pelvis and its nerve supply, leading to prolapse. The 
Oxford Family Planning association prolapse epidemiological study, has shown parity to be the strongest risk factor for the development of POP with an adjusted relative risk of $10.85(4.65-33.81) .^{3}$ Increased risk of POP with menopause while supported by this study and that by swift et al, the Progetta menopausa study group do not support the view. ${ }^{5,6}$

This study did not find an association between difficult delivery and prolapse but Samuelsson et al have reported an increased incidence of prolapse with an increase in birth weight which was statically significant. ${ }^{4}$ In tandem with our finding, a study of 21,449 Italian women attending a menopausal clinic reported no significant increase in POP with delivery of babies weighing more than 4500 gms. $^{6}$

This study shows wider GH and PB with valsalva in the cases as compared to the controls. The mean increase in $\mathrm{GH}$ and PB with valsalva in patients with POP included in this study was $2.76 \pm 0.91 \mathrm{~cm}$ and $1.12 \pm 0.54 \mathrm{~cm}$ respectively. Although there are not many studies on this till date, a study by Anthony $\mathrm{G}$ et al reported a mean increase of $0.79 \pm 0.78 \mathrm{~cm}$ and and $0.19 \pm 0.43 \mathrm{~cm}$ in $\mathrm{GH}$ and $\mathrm{PB}$ with valsalva in prolapse patients. ${ }^{17}$ The results of this study regarding positive association of levator hiatus ballooning with urinary sumptoms is in agreement with studies by Azar Khunda et al, where they concluded that the sum of GH and PB measurements obtained during a clinical examination using the ICS POP Q is a strong predictor of symptoms and signs of prolapse. ${ }^{18}$

\section{CONCLUSION}

- $\quad$ There is more prevalence of POP after 40 years of age. Etiologic association of this problem is found with higher parity

- Menopause also predisposes to POP.

- As compared to women without prolapse, in pateints of POP, the dimensions of $\mathrm{GH}$ and $\mathrm{PB}$ are higher. Also, increase in their values in more with valsalva in patients than controls.

- Measurements of POPQ when taken during valsalva, tend to give a better picture of levator dysfunction in prolapse patients.

Funding: No funding sources

Conflict of interest: None declared

Ethical approval: The study was approved by the Institutional Ethics Committee

\section{REFERENCES}

1. Bump RC, Mattiason A, Bo K, Brubaker LP, DeLancey JO, Klarskov $\mathrm{P}$ et al. The standardization of terminology of female pelvic organ prolapsed and pelvic floor dysfunction. AJOG. 1996;175:10-7.
2. Visco AG, Wie JT, Mcclure LA, HandaVL. Effects of examination technique modification on POPQ results. Int Urogyn J. 14:136-40.

3. Mant J, Painter R, Vessey M. Epidemiology of genital prolapsed :observations from the Oxford Family Planning Association study. $\mathrm{Br} \mathrm{J}$ Obstet Gyncaecol. 1997;104:579-85.

4. Samuelsson EC, Victor FTA, Tibblin G, Svardsudd KF. Signs of genital prolapsed in Swedish population of women 20 to 59 years of years of age and possible related factors. Am J Obstet Gynecol. 1999;180:299-305.

5. Swift SE. The distribution of pelvic organ support in a population of female subjects seen for routine gynaecologic health care. Am J Obstet Gyncol. 2000;183:277-85.

6. Progetto Menopausa Italia Study Group. Risk factors for genital prolapsed in non-hysterectomized women around menopause. The results from a large cross sectional study in menopausal clinics in Italy. Eur $\mathbf{J}$ Obstet Gyncol Reproduc Biol. 2000;93:125-40.

7. Oslen AL, Smith VJ, Bergstrom JO, Colling JC, Clark AL. Epidemiology of surgically managed pelvic organ prolapse and urinary incontinence. Obstet Gyncol. 1997;89:501-6.

8. Rinne KM, Kirkinen PP. What predisposes young women to genital prolapsed? Eur J Obstet Gyncol Reprod Biol. 1999;84:23-5.

9. Snooks SJ, Swash M, Henry MM, Setchel M. Risk factors in childbirth causing damage to pelvic floor innervations. Int J Colorectal Dis. 1986;1:20-4.

10. Gilpin SA, Gosling JA, Smith ARB. The pathogenesis of genitourinary prolapsed and stress incontinence of urine. A histochemical study. Br J Obstet Gyn. 1989;96:15-23.

11. Smith ARB, Hosker GL, Warrell DW. The role of partial dennervation in the etiology of prolapse and SUI, A Neurophysiogic study. Br J Obstet Gyncol. 1989;96:24-8.

12. Jones PN, Lubowski DZ, Swash M, Henry MM. Relation between perineal descent and pudendal nerve damage in idiopathic fecal incontinence. Int $\mathbf{J}$ Colorectal Dis. 1987;2:93-5.

13. Lubowski DZ, Swash M, Nichols J, Henry MM. Increases pudendal nerve terminal motot latency with defecation straining. Br J Surg. 1988;75:1095-7.

14. Spence Jones C, Kamm MA, Henry MM, Hudson CN. Bowel dysfunction: A pathogenic factor in uterovaginal prolapse and urinary stresss incontinence. Br J Obstet Gyncol. 1994;101:147-52.

15. Davis GD. Uterine prolapsed after laparoscopic uterosacral transaction in nulliparous trainees: a report of three cases. J Reprod Med .1996;41:279-82.

16. Khunda A, Shek KL, Dietz HP. Can Ballooning of levator hiatus be determined clinically? Am J Obstet Gyncol. 2012;206:246.e1-4.

17. Visco AG, Wei JT, McClure LA, Handa VL, Nygaard IE. Effects of examining technique modifications on pelvic organ prolapsed 
quantification (POP-Q) results. Int Urogynecol J Pelvic Floor Dysfunct. 2003;14(2):136-40.

18. Khunda A, Shek KL, Dietz HP. Can Ballooning of the levator hiatus be determined clinically? Am J Obstet Gynecol. 2012;206:246.e1-4.
Cite this article as: Hota T, Misra S. Pelvic organ prolapse quantification system: to valsalva or not to valsalva while measuring genital hiatus $(\mathrm{GH})$ and perineal body (PB). Int J Reprod Contracept Obstet Gynecol 2017;6:1843-7. 